\section{An energetic company}

ELECTRONIC devices, without moving parts, are unspectacular to look at, but Central Electronics Ltd, at Sahibabad in the eastern suburbs of Delhi, has made electronics fun. Its stock in trade is the production of solar cells for the production of electricity. Its director, M. R. Narayanan, is a retired Indian Amry brigadier with interests on the signals side who seems to have been captivated by turning India's endless sunshine into power.

That the trick is possible is plain for all visitors to see. In a crudely constructed shed on CEL's substantial campus, there is a display of working models, many of them aimed at India's village folk, all driven from a solar collector on the roof. For example, there is a kind of portable hurricane lamp whose battery is recharged by the solar collector when not being moved.

And, inevitably, there is a solarpowered television set, which in real life might be the medium for disseminating improving information to the villages. CEL has also discovered the need for rudimentary lighting systems, perhaps in evening classes, and has built a room to show off that prospect. For semi-urban India, CEL's brochures also show a solar-powered petrol pump.

But the neatest device, entirely consonant with Narayanan's first career, is a portable solar collector consisting of half a dozen square-foot silicon surfaces that fold neatly into a canvas square that can be fixed to a backpack. The idea is that, when laid out in sunlight, they produce enough power to charge an accumulator in a reasonably short time, thus making it possible to operate a radio from some remote location. The benefit, for soldiers, is that a spare accumulator does not have to be taken along.

That is CEL's shop window. Its strength is its experience in hitching up solar collectors to the devices that will use the power they produce. Working on the principle that there is plenty of sunlight anyway, the laboratory is aiming at achieving reliability rather than striving for the ultimate in efficiency. (It reckons that its silicon modules can convert 13 per cent of the sunlight they collect into electricity.) At one point during a walk through the production plant, Narayanan lifted one of several modules of silicon cells from a stack and dropped it face-down on the concrete floor just to demonstrate its ruggedness.

In practice, it appears that the basic (but still evolving) design of the standard crystalline silicon module (which is a little larger than a small floppy disk) is less
SOLAR PHOTOVOLTAIC POWER SOURCE FOR PANEL STATION OF INDIAN RAILWAYS

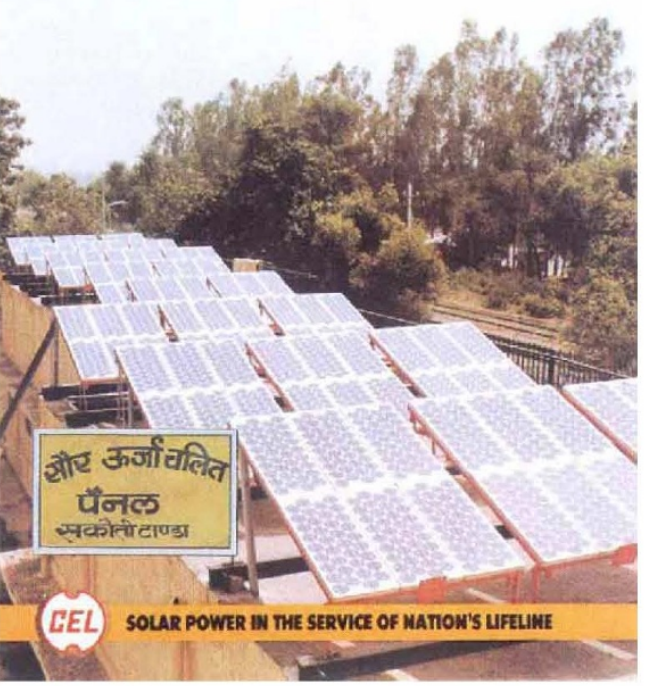

ew applications escape CEL.

important than the arrangement of the small components into a power-producing module (the spaces in between, and their texture, matter) and the collection of the current. CEL has for the time being settled on a modular solar collector just over one square metre in area, which can produce $3.3 \mathrm{~kW}$ of power at its peak. That is enough to pump water from a shallow depth for about 2 hours a day.

The intricacies, which are not part of high technology, come with the processing of the power. To iron out night and day (and the rare occasions when the Sun is not shining) power must be stored in batteries and even converted from d. c. to a. c. The accumulator is a bulky (and costly) item, and may not last for long if it is overcharged or allowed to run too flat, as is the convertor.

So how quickly will Narayanan's solar cells help to defeat the threats of acid rain and global warming, on which he has set his sights? The soldier turned salesman is ever ingenious in the search for customers; at least one off-shore oil-drilling rig has been fitted out, but there is also, alongside the campus helicopter pad, the essence of a $1,000 \mathrm{~kW}$ installation that may just about supply CEL with power. There is also a plan for $10 \mathrm{MW}$ station in an isolated township nearer the Himalayas.

But the Eighth Plan is cool on the prospects for solar voltaics. Cost, it says, continue to be a major constraint in the expansion of the programme. In a familiar note, the plan says that energy conservation is still the more economic course to follow.

\section{A future} \section{in bamboo}

MAKING bamboo plants flower at will may seem an esoteric enterprise, but it has become one of the chief interests of the National Chemical Laboratory (NCL) at Pune. The point is that, in the wild, bamboos flower only at unpredictable intervals, perhaps after 30 years or more. The result is that conventional plantbreeders are hampered, to say the least of it, in seeking crosses between different varieteies and species.

But no longer. Since 1990 and the publication of a paper (Nature 344, 355; 1990) by R. S. Nadgauda, V. A. Parasharami and A. F. Mascarenhas showing that the flowering of bamboo could be induced at will, NCL has been up to its eyes in the exploitation of the phenomenon. The objective is to use the system for interbreeding between varieties and species using pollen and seeds collected from flowers induced to flower artificially.

The technique, which relies on an empirically derived broth whose active principles have not yet been characterized, has been made to work with most (but not all) bamboo species, from India and eleswhere. The group at Pune has shown that immature seeds collected from induced flowering can be fertilized and mature plants grown from resulting embryos. But attempts to induce flowering of mature plants have so far failed, suggesting that the technique will work only in vitro.

That should suffice. Bamboo is a versatile crop widely used in India for construction and as fodder. It should not be long before the NCL has improved specialized strains on the market, when it will be interesting to see whether it follows Western seed distributors in seeking royalties on the crops that arise.

But Dr A. R. Mashelkar, director of the $\mathrm{NCL}$, has other fish to fry - one of them a scheme to manufacture carbamate pesticides in India by processes other than that responsible for the tragedy at the Union Carbide plant at Bhopal exactly ten years ago. (The process is now banned in India.) The alternative involves the condensation of alkyl carbamates with phenols, but Mashelkar has now put his faith in still another alternative, involving the reaction of high-pressure carbon dioxide with amines. Green chemistry is his slogan.

Equipped with large-scale pilot plants, NCL works closely with the chemical industry in India on the development of novel processes, many using zeolite catalysts. Mashelkar has much to say about globalization. He insists that India is capable of meeting the challenge in chemical manufacture; The mood is there, the question is how fast you can go. 